\title{
2. Coal comfort Pacific islands on collision course with Australia over emissions
}

Commentary: During 2017, Fiji is president of negotiations under the United Nations Framework Convention on Climate Change (UNFCCC). It is the first time the talks have been headed by a Small Island Developing States (SIDS), and Fiji's Prime Minister, Voreqe Bainimarama, plans to use the 23rd Conference of Parties (COP23) to highlight the impacts of climate change on island states. Even as Pacific island leaders demand greater action to reduce emissions, the Australian government is supporting new coal mines at home and a dramatic increase in coal exports. This commentary focuses on Pacific leadership in the global fight to avoid catastrophic changes to the climate system. It suggests determined diplomacy by island states may help shift international opinion in favour of urgent action to reduce emissions. However, Pacific states must first shine a spotlight on their recalcitrant neighbour, and avoid being silenced by Australian 'climate diplomacy'.

Keywords: Adani, climate change, climate negotiations, coal, COP23, energy, Fiji, Pacific Islands

\section{WESLEY MORGAN}

The University of the South Pacific, Suva

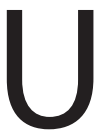

NIQUELY vulnerable to the impacts of a warming world, Pacific island countries have long been considered the front-line of climate change, so it is not surprising that they are also leading the fight to tackle the problem.

These oceanic nations have vowed to challenge major polluters to cut emissions and, this year, they have coal exports from their biggest neighbour firmly in their sights.

For the first time, a Pacific island country is head of global negotiations aiming to limit 'dangerous interference' with the Earth's climate system. Fiji, which in February marked the first anniversary of the devastation caused by the strongest cyclone ever recorded in the Southern Hemisphere, has vowed to use its presidency of the United Nations Framework Convention on Climate Change (UNFCCC) to make the world sit up and take notice (Armbruster, 2017; see also UNFCCC, 2017). 

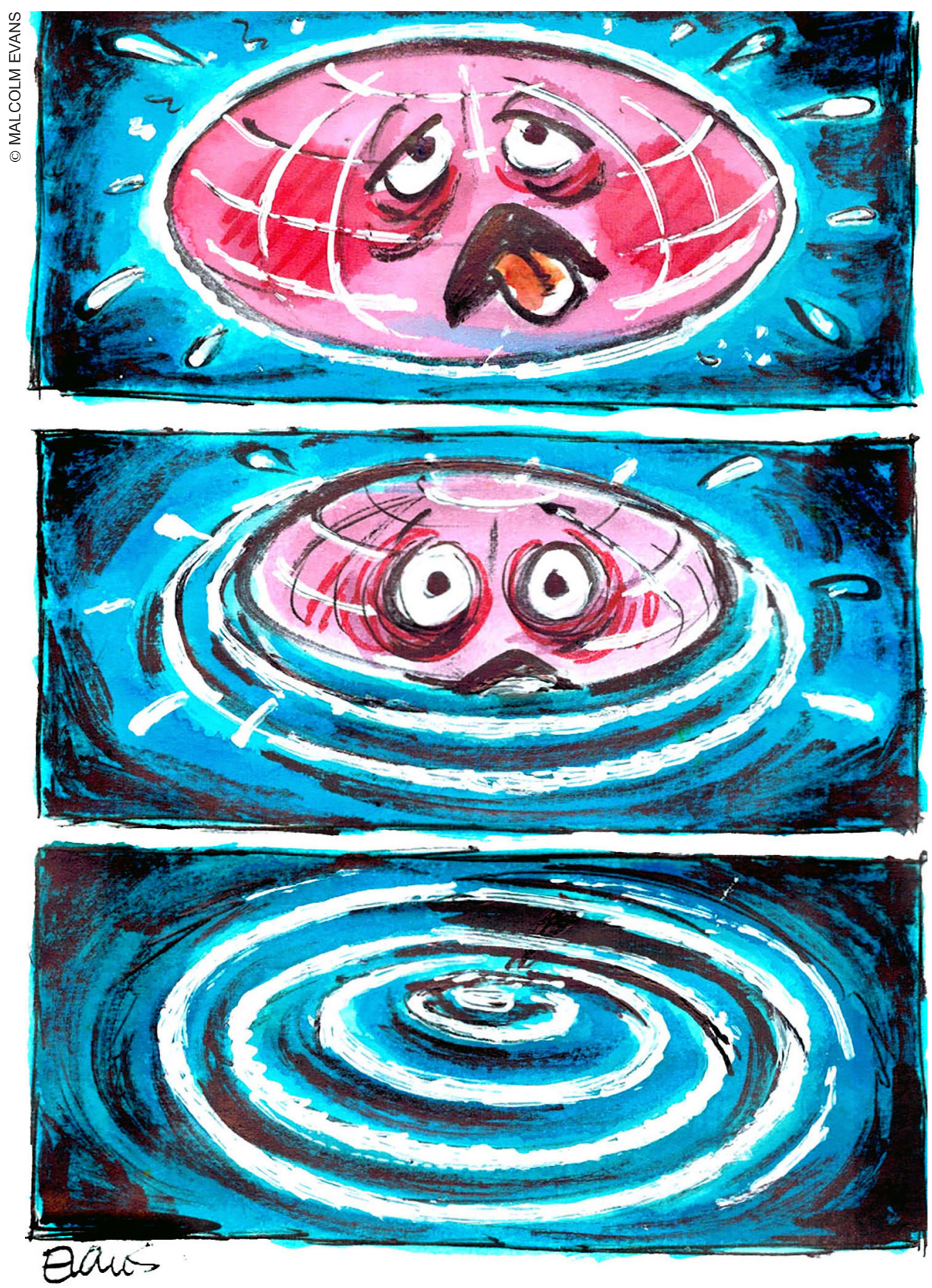

This must be a matter of concern in Australia's capital, Canberra; Fiji's Prime Minister Voreqe Bainimarama is an outspoken critic of his neighbour's climate policy. He has labelled Australia a prominent member of the 'coalition of the selfish'- a group of industrialised nations that put the welfare of their carbon- 
polluting industries before the environment, and even the survival of Pacific island countries (Callick, 2015).

It is difficult to deny that Bainimarama has a point. Australia is one of the wealthiest nations on earth, and the world's largest coal exporter. The country has doubled exports of coal — the dirtiest of fossil fuels — over the past decade (see Frydenberg, 2016).

Far from scaling back on coal as part of global efforts to reduce emissions, Australia is currently planning public subsidies for new coal mines and considering financing new coal-fired power plants (see Belot, 2017).

Abroad, Australian diplomats are tasked with improving coal's reputation. Late in 2016, for example, they lobbied the newly established Asian Infrastructure Investment Bank to ensure multilateral finance would be directed toward so-called "clean coal" power plants in the region (Smyth and Hornby 2016).

Australia's aggressive promotion of coal has angered Pacific island governments, which have repeatedly called for a global moratorium on the development of new coal mines (Radio New Zealand, 2015). In October 2015, Bainimarama issued a special plea for Prime Minister Malcolm Turnbull to 'impose a moratorium on the development of further reserves of Australian coal' (Bainimarama, 2015).

Australia's continued promotion of coal is also firmly at odds with the 2015 Paris Agreement, which aims to limit global warming to well below $2{ }^{\circ} \mathrm{C}$ above the pre-industrial average. To have a reasonable chance of achieving that goal, there is little doubt the vast majority of the world's coal reserves must stay in the ground (UNFCCC, 2015).

Wary that Fiji and other Pacific island countries will again target Australia at the COP23 climate negotiations in December 2017, Australian Ambassador for the Environment Patrick Suckling was dispatched to island capitals in February 2017 to promote Australia's climate change 'credentials' (see Sanerivi, 2017).

Having been set the task of promoting carbon emissions to people on lowlying atolls - surely the 21 st century equivalent of selling ice to Eskimos-Ambassador Suckling visited Tuvalu, Samoa and Fiji to explain that 'clean coal' would be part of the world's energy mix for decades (Vucago, 2017a).

Perhaps it is not surprising that he was happy to promote the benefits of coal; in his previous role as ambassador to India, Suckling encouraged the Indian firm Adani to invest in a new coal mine in the Australian state of Queensland. In July 2014, he described the proposed Carmichael mine, which, if completed, will be the largest coal mine in the Southern Hemisphere, as an 'outstanding project' (Australian High Commission, New Delhi, 2014).

Suckling's island tour, and his support for coal, sparked outrage from Pacific island civil society and church groups, who penned an open letter to the ambassador calling on the Australian government to do more to reduce emissions (Radio New Zealand, 2017; Jackson, 2017). 
While in Fiji, Ambassador Suckling suggested Australia would work closely with the country to ensure the 2017 global climate negotiations would be a success. He also made much of Australia's role as co-chair of the UN's Green Climate Fund, suggesting new finance would help Pacific communities build resilience to a changing climate (Vucago, 2017b; see also Kumar, 2017).

This year, Australia co-chairs the Green Climate Fund with another nation that has the dubious honour of being a leading exporter of carbon: Saudi Arabia. By 2020, Australia is expected become the world's largest exporter of both coal and natural gas (Frydenberg, 2016).

When that happens, Australia's total carbon exports look set to exceed that of Saudi Arabia - the world's largest oil exporter (Pearse, 2016).

Pacific island states are no doubt wary of wolves in sheep's clothing. They are well aware that both Australia and Saudi Arabia have a history of dragging their feet on global efforts to reduce carbon emissions. In the lead up to negotiations for the 1997 Kyoto Protocol, for example, Australia was isolated with Saudi Arabia (and other OPEC members) and Russia as the minority of laggard states (Oberther \& Ott, 1999, p. 54).

At the climate negotiations that followed, the country insisted on special exemptions - subsequently known as 'the Australia clause' - that allowed it to meet international commitments even while domestic emissions from burning fossil fuels increased (Hamilton, 2015). Concerned with safeguarding its oil exports, Saudi Arabia has long been accused of outright obstruction in climate negotiations (Depledge, 2008, p. 9).

Pacific island governments are familiar with Australia's repeated attempts to weaken their position at UN climate negotiations (Morgan, 2016). Indeed, at each major milestone in the global talks, Australia has exercised an effective veto power at the Pacific Islands Forum (PIF) - the region's premier annual political meeting - to water down positions put forward by its small, impoverished neighbours.

In 1997, for example, island leaders wanted to issue a declaration calling for a global agreement that included legally binding commitments to reduce emissions. But they were 'bullied into submission' by then Australian Prime Minister John Howard, who secured a toned-down declaration (CNN, 1997).

In the lead-up to negotiations for the 2015 Paris Agreement, Australian officials again worked hard to ensure the Pacific Islands Forum leaders' statement accommodated Australia's position in the global talks (Pacific Islands Forum, 2015).

Most pointedly, the 2015 Forum leaders' declaration on Climate Change Action failed to repeat earlier calls by Pacific island leaders for a global agreement to limit warming to below $1.5^{\circ} \mathrm{C}$ above the pre-industrial average (see Fry, 2015).

Pacific island states insist that warming beyond this 1.5 degrees threshold 
would threaten the very survival of low-lying states in the region, such as Kiribati, Tuvalu and the Marshall Islands (see Radio New Zealand, 2016).

Fiji has vowed to use its UNFCCC presidency to maintain the momentum that was established by the 2015 Paris Agreement. Widely seen as a diplomatic breakthrough, that agreement represents a shared political commitment to reducing carbon emissions.

But global climate talks now stand at an important crossroads. Officials are still finalising the rule book to accompany the agreement, even as the first global stocktake of pledges made under it is planned for next year.

It is crucial that ambitious and transparent pledges are made. Polluting nations must reduce greenhouse gas emissions quickly, before catastrophic rates of warming are locked in.

Pacific island countries have a special role to play in convincing the international community to start the needed shift to a zero emissions global economy. With the world's eyes on them at COP23, which is already being labelled the 'Pacific COP', island leaders have the opportunity to highlight what must be done to give low-lying Pacific countries a fighting chance at a future.

But first they must continue to shine the spotlight on their recalcitrant neighbour, and take care to avoid being muzzled by Australia's 'climate diplomacy'.

\section{References}

Armbruster, S. (2017, February 20). A year after Cyclone Winston, Fiji calls for global action on climate change. SBS News Online. Retrieved on 19 April 2017, from http:// www.sbs.com.au/news/article/2017/02/20/year-after-cyclone-winston-fiji-callsglobal-action-climate-change

http://india.highcommission.gov.au/ndli/pa2314.html

Bainimarama, V. (2015, October 28). Hon PM Bainimarama speech at the closing of the Pacific ministers' meeting on strengthening climate change resilience. Retrieved on 21 April 2017, from http://www.fiji.gov.fj/Media-Center/Speeches/HON-PMBAINIMARAMA-SPEECH-AT-THE-CLOSING-OF-PACIFI.aspx

Belot, H. (2017, February 2). Clean energy subsidies could be used to build new coal power plants, Scott Morrison says. ABC News Online. Retrieved on 19 April 2017, from http://www.abc.net.au/news/2017-02-02/clean-energy-money-could-fund-coalpower-stations-morrison-says/8234118

Callick, R. (2015, May 7). Fiji's Bainimarama blasts Australia's 'coalition of the selfish. The Australian. Retrieved on 19 April 2017, from http://www.theaustralian.com.au/ news/world/fijis-bainimarama-blasts-australias-coalition-of-the-selfish/news-story/ a49a7be2d33585cea3bb48174a006424

CNN. (1997, September 20). Australia in hot water over global warming stance. Cable News Network Interactive. Retrieved on 19 April 2017, from http://edition.cnn.com/ WORLD/9709/20/pacific.forum/index.html?eref=sitesearch

Depledge, J. (2008). Striving for No: Saudi Arabia in the Climate Change Regime. Global Environmental Politics, 8(4), 9-35. 
Fry, G. (2015, September 21). Pacific Islands Forum: climate 'consensus' on the road to Paris. The Strategist. Australian Strategic Policy Institute. Retrieved on 21 April 2017, from https://www.aspistrategist.org.au/the-pacific-islands-forum-declarationon-climate-change-consensus-at-the-cost-of-strategy-on-the-road-to-paris/

Frydenberg, J. (2016, March 22). Opportunities and challenges in Australia's resources and energy sectors. Speech by Minister for Resources, Energy and Northern Australia, Josh Frydenberg. Retrieved on 19 April 2017, from http://minister.industry.gov.au/ ministers/frydenberg/speeches/opportunities-and-challenges-australias-resourcesand-energy-sectors

Hamilton, C. (2015, July 16). Australia hit its Kyoto target, but it was more a three-inch putt than a hole in one. The Conversation. Retrieved on 19 April 2017, from https:// theconversation.com/australia-hit-its-kyoto-target-but-it-was-more-a-three-inch-puttthan-a-hole-in-one-44731

Jackson, C.J. (2017, February 5). An open letter from the Pacific Islands Climate Action network to the Australian Ambassador for Climate Change, Patrick Suckling. The Huffington Post. Retrieved on 19 April 2017, from http://www.huffingtonpost.com/entry/anopen-letter-from-the-pacific-islands-climate-action_us_5897a1dfe4b061551b3e0049

Kumar, V. (2017, January 31). \$60m from climate grant set aside for Fiji. The Fiji Times. Retrieved on 19 April 2017, from http://www.fijitimes.com/story.aspx?id=387422

Morgan, W. (2016, September 7). Pacific pariah: how Australia's love of coal has left it out in the diplomatic cold. The Conversation. Retrieved on 21 April 2017, from https://theconversation.com/pacific-pariah-how-australias-love-of-coal-has-left-itout-in-the-diplomatic-cold-64963

Oberther, S. \& Ott, H. (1999). The Kyoto protocol: International climate policy for the 21st century. Springer, Berlin.

Pacific Beat. (2015, August 11). Marshall Islands foreign minister Tony de Brum slams Australia's proposed 2030 carbon emissions targets. ABC News. Retrieved 21 April 2017 from http://www.abc.net.au/news/2015-08-11/marshall-islands-slams-australiascarbon-emissions-targets/6688974?pfmredir $=\mathrm{sm}$

Pacific Islands Forum. (2015) Pacific Islands Forum leaders' declaration on climate change action. Retrieved on 21 April 2017, from http://www.forumsec.org/resources/ uploads/attachments/documents/Annex1_PIF_Leaders_Declaration_on_Climate Change_Action, \%2010Sept2015.pdf

Pearse, G. (2016, July 23). Truth about Australia's coal industry and climate policy. The Saturday Paper. Retrieved on 21 April 2017, from https://www.thesaturdaypaper. com.au/opinion/topic/2016/07/23/truth-about-australias-coal-industry-and-climatepolicy/14691960003525

Radio New Zealand. (2017, February 15). PICAN says Australian climate claim not rational. Radio New Zealand International. Retrieved on 21 April 2017 from http:// www.radionz.co.nz/international/programmes/datelinepacific/audio/201833311/ pican-says-australian-climate-claim-not-rational

Radio New Zealand. (2016, November 9). Pacific pushing for 1.5 degree commitment at COP22. Radio New Zealand International. Retrieved on 21 April 2017, from http:// www.radionz.co.nz/international/pacific-news/317697/pacific-pushing-for-1-point5-degree-commitment-at-cop-22

Radio New Zealand. (2015, September 8). Small islands call for global moratorium on coal mines. Radio New Zealand International. Retrieved on 21 April 2017, from http://www.radionz.co.nz/international/pacific-news/283565/small-islands-call-forglobal-moratorium-on-coal-mines 
Sanerivi, S. (2017, February 9) Ambassador assures Samoa. Samoa Observer. Retrieved on 21 April 2017, from http://samoaobserver.ws/en/09_02_2017/local/16685/ Ambassador-assures-Samoa.htm

Smyth, J. \& Hornby, L. (2016, December 16). Australia lobbies China-led AIIB to add coal to lending priorities: Australia seeks to defend its lucrative exports to the region. Financial Times. Retrieved on 19 April 2017, from https://www.ft.com/ content/68ed504a-c110-11e6-9bca-2b93a6856354

United Nations Framework Convention on Climate Change. (2017, January 13). Sit up and take notice of climate change: Fijian prime minister sets out COP23 priorities. UN Climate Change Newsroom. Retrieved on 19 April 2017, from http://newsroom.unfccc.int/unfccc-newsroom/world-needs-to-sit-up-and-take-notice-of-climate-change/

United Nations Framework Convention on Climate Change. (2015, January 8) Most fossil fuels must stay in the ground: New Study. UN Climate Change Newsroom. Retrieved on 19 April 2017, from http://newsroom.unfccc.int/unfccc-newsroom/ most-fossil-fuels-must-stay-in-the-ground-new-study/

Vucago, A. (2017a, February 7). Plans for carbon cuts. The Fiji Times. Retrieved on 19 April 2017, from http://www.fijitimes.com/story.aspx?id=388360

Vucago, A. (2017b, February 6). Aussies back Fiji. The Fiji Times. Retrieved on 19 April 2017, from http://www.fijitimes.com/story.aspx?id=388207

Dr Wesley Morgan is a lecturer in politics and international affairs in the School of Government, Development and International Affairs at the University of the South Pacific. His research interests include Pacific island diplomacy; the politics of Pacific regionalism; Pacific participation in international trade negotiations; Pacific participation in global climate change negotiations; the future of agriculture in the Pacific; and leadership and governance in Vanuatu. morgan.wesley@usp.ac.fj 